\title{
Influence of the wind on water application uniformity of a mechanical lateral move irrigation equipment using rotating plate sprinklers
}

\author{
Influência do vento na uniformidade de aplicação de água de um equipamento de irrigação \\ mecanizada tipo lateral móvel usando emissores de placa oscilante
}

\author{
Lessandro Coll Faria $^{\mathrm{I}^{*}}$ Samuel Beskow ${ }^{\mathrm{I}}$ Alberto Colombo ${ }^{\mathrm{II}}$ Bernardo Gomes Nörenberg ${ }^{\mathrm{III}}$ \\ Osvaldo Rettore Neto ${ }^{\text {IV }}$ Matheus Chagas Simões ${ }^{\mathrm{V}}$
}

\begin{abstract}
Investigations demonstrate that the wind is the factor that causes the biggest negative influence on water application of sprinkler irrigation systems. Therefore, this paper aims to evaluate, in in-field conditions, the influence of wind on the water distribution uniformity of a mechanical lateral move sprinkler system used for irrigation in rice crop in the South of Rio Grande do Sul State, Brazil. The equipment is located at the Campo Experimental de Terras Baixas (ETB) of EMBRAPA/CPACT and operates with water emitters model I-Wob installed in drop tubes in a distance of $2.8 \mathrm{~m}$ above the soil surface, having a uniform space of $2.3 \mathrm{~m}$ between each other and pressure regulators of $68.9 \mathrm{kPa}$. Sixteen in-field evaluations were done and they permitted to infer that the higher is the wind speed, the lower are the values of Christiansen Uniformity (CU) and of Distribution Uniformity (DU) coefficients. Besides, it can be affirmed that even in unfavorable wind conditions, the mechanical lateral move irrigation equipment presented desirable indexes of water application uniformity.
\end{abstract}

Key words: irrigated rice, sprinkler, in-field tests, irrigation uniformity.

\section{RESUMO}

Estudos demonstram que o vento é o fator que causa maior influência negativa na aplicação de água de sistemas de irrigação por aspersão. Sendo assim, este estudo tem por objetivo avaliar, em condições de campo, a influência do vento sobre a uniformidade de distribuição de água de um sistema mecanizado do tipo lateral móvel, utilizado na irrigação de arroz no sul do Rio Grande do Sul. $O$ equipamento, localizado no Campo Experimental de Terras Baixas (ETB) da EMBRAPA/CPACT, opera com emissores de água modelo I-Wob instalados em tubos pendurais a uma distância de 2,8m da superfície do solo, espaçados uniformemente entre si em $2,3 \mathrm{~m}$, com reguladores de pressão de $68,9 \mathrm{kPa}$. As 16 avaliações de campo realizadas permitiram inferir que quanto maior a velocidade do vento menor os valores dos coeficientes de uniformidade de Christiansen $(C U)$ e de distribuição (UD). Além disso, pode-se afirmar que, mesmo em condições adversas de vento, o equipamento de irrigação mecanizada do tipo lateral móvel apresentou índices desejáveis de uniformidade de aplicação de água.

Palavras-chave: arroz irrigado, aspersão, ensaios de campo, uniformidade de irrigação.

\section{INTRODUCTION}

Irrigation is widely used in Rio Grande do Sul State, Brazil, guaranteeing productivity in times of water shortage and rising the quality of agricultural products. Usually, irrigated agriculture has greater productivity compared to dryland farming and, according to CRUSCIOL et al. (2012), sprinkler irrigation in rice culture also allows to obtain seeds with higher physiological quality in comparison to the ones produced in drylands.

An increase in adoption of sprinkler irrigation systems should be closely followed, aiming to the maximization of the efficiency in water application by these systems, and therefore, the optimization in use of the available water resources

ICentro de Desenvolvimento Tecnológico/Engenharia Hídrica, Universidade Federal de Pelotas (UFPel), 96010-610, Pelotas, RS, Brasil.

Corresponding author:E-mail: lessandro.faria@ufpel.edu.br. "Corresponding author

${ }^{I I}$ Departamento de Engenharia, Universidade Federal de Lavras (UFLA), Lavras, MG, Brasil.

IIIPrograma de Pós-graduação em Recursos Hídricos, UFPel, Pelotas, RS, Brasil.

${ }^{\text {IV }}$ Departamento de Engenharia Rural, Faculdade de Agronomia Eliseu Maciel, UFPel, Pelotas, RS, Brasil.

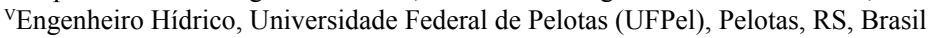


(TOROMO et al., 2011). It can be emphasized that, in Brazil, there are few studies related to the evaluation of mechanical lateral move sprinkler irrigation systems considering the wind conditions. Besides, studies about weather conditions in Rio Grande do Sul State related to the efficiency of these systems are unknown.

HEINEMANN et al. (1998) emphasize that irrigation systems should provide a uniform and efficient water application due to the importance and the current evidence in water management, to their competitiveness among different sectors of the society, to energy and agricultural inputs costs. Thus, BESKOW et al. (2011) affirm that despite the wide use of sprinkler irrigation systems, they frequently do not operate with their fullest efficiency due to wrong design or their use in unfavorable weather conditions, thus causing the waste of water, energy and fertilizers.

A way to evaluate an irrigation system is through uniformity coefficients that make it possible to express the variability of irrigation depth levels applied over the irrigated area. However, several factors may influence on water distribution uniformity of sprinkler irrigation systems, more noticeably the wind speed during an irrigation event (KELLER \& BLIESNER, 1990).

According to DECHMI et al. (2003), evaluation of irrigation uniformity under field conditions is the most recommended option to analyze the performance of an irrigation system. Yet, these authors point out that wind has great influence on irrigation uniformity such that the greater the wind speed, the less the uniformity coefficients. KINCAID (1996) and SANCHEZ et al. (2011) go along with DECHMI et al. (2003) in affirming wind strongly affects the sprinkler irrigation performance. KINCAID (1996) also states that it is necessary to advance in the technical knowledge and to develop tools in order to improve the performance of sprinkler irrigation systems operating under windy conditions.

Thus, the goal of this paper was to evaluate, in in-field conditions, the influence of the wind on the water distribution uniformity of a mechanical lateral move sprinkler system used for irrigation in rice crop in the South of Rio Grande do Sul State, Brazil.

\section{MATERIAL AND METHODS}

Study area and irrigation system

The linear move sprinkler irrigation system evaluated in this study was installed at the
Campo Experimental de Terras Baixas - ETB of Empresa Brasileira de Pesquisa e Agropecuária EMBRAPA, Centro de Pesquisa Agropecuária de Clima Temperado - CPACT.

The climate in this region, according to Köppen's classification, is humid temperate with hot summer (Cfa). This place is representative of the subtropical, maritime environment, having subhumid summer and humid or superhumid climate in the rest of the year (GONÇALVES et al., 2014). The equipment was manufactured by Valley company and has the following technical characteristics: length of $265 \mathrm{~m}, 5$ spans, it is equipped with Senninger water emitters, model I-Wob, nozzle number $16\left(6.35 \mathrm{~mm}\right.$ and $\left.1313 \mathrm{~L} \mathrm{~h}^{-1}\right)$ and rotating plate of 9 jets.

Emitters I-Wob are installed in flexible drop hoses, with counter weight, positioned in a distance of $2.8 \mathrm{~m}$ from the soil surface, having a uniform space of $2.3 \mathrm{~m}$ between each other and equipped with pressure regulators of $68.9 \mathrm{kPa}(10 \mathrm{psi})$, according to the manufacturer specifications. Motorized pump set is equipped with a diesel engine capable of providing $43.4 \mathrm{cv}$ power in the crankshaft linked to a centrifugal pump, with nominal flow rate of $180 \mathrm{~m}^{3} \mathrm{~h}^{-1}$ and manometric head of $30 \mathrm{mwc}$.

In-field tests of the lateral move equipment

Sixteen in-field tests were carried out with the mechanical lateral move sprinkler system in March, 2014, during rice crop irrigation in the study region. Thus, tests to evaluate the performance of the equipment were conducted in real operational conditions. Tests to evaluate the water distribution unifomity of the linear move equipment were done according to the technical norms of NBR 14244 (ABNT, 1998) and S436.1 (ASAE, 1996).

The catch cans used had a collecting area equivalent to $50.265 \mathrm{~cm}^{2}$ and $8 \mathrm{~cm}$ in depth, and they were installed $70 \mathrm{~cm}$ over the ground. Tests were done with two lines of catch cans, installed in parallel with the linear move equipment, distant $5 \mathrm{~m}$ from each other. In each line 88 catch cans were installed, having a space of $3 \mathrm{~m}$ between each other. The water volume in each collector was measured, as soon as the test finished, using a $100 \mathrm{~mL}$ graduated glass cylinder with subdivisions in each $1 \mathrm{~mL}$.

Weather variables relevant to this study were monitored by a Davis weather station, Vantage Pro2 Plus model, installed about $50 \mathrm{~m}$ far from the irrigated area, $2 \mathrm{~m}$ over the ground. The information related to each variable was registered in a data logger 
in 1-minute time step. Besides, starting and finishing time of each water distribution test of the linear move equipment were registered.

Data processing of the in-field tests

The water distribution uniformity coefficients used in this study were the Christiansen uniformity coefficient (CU, in \%), proposed by CHRISTIANSEN (1942), Equation 1 , and the distribution uniformity coefficient (DU, in \%), proposed by CRIDDLE et al. (1956), Equation 2.

$$
\mathrm{CU}=\left[1-\frac{\sum_{\mathrm{i}=1}^{\mathrm{N}}\left|\mathrm{X}_{\mathrm{i}}-\overline{\mathrm{X}}\right|}{\mathrm{N} \cdot \overline{\mathrm{X}}}\right] \cdot 100
$$

$$
\mathrm{DU}=\left[\frac{\overline{\mathrm{X}}_{25 \%}}{\overline{\mathrm{X}}}\right] \cdot 100
$$

Where:

$\mathrm{X}_{\mathrm{i}}$ - irrigation depth collected in the i-th catch can, $\mathrm{mm}$.

$\overline{\mathrm{X}}$ - average irrigation depth, $\mathrm{mm}$.

$\mathrm{N}$ - number of catch cans.

$\bar{X}_{(25 \%)}$ - average irrigation depth of the. $25 \%$ of the lower collected values, $\mathrm{mm}$.

\section{RESULTS AND DISCUSSION}

Figure 1 depicts the water distribution patterns throughout the lateral of the equipment, for

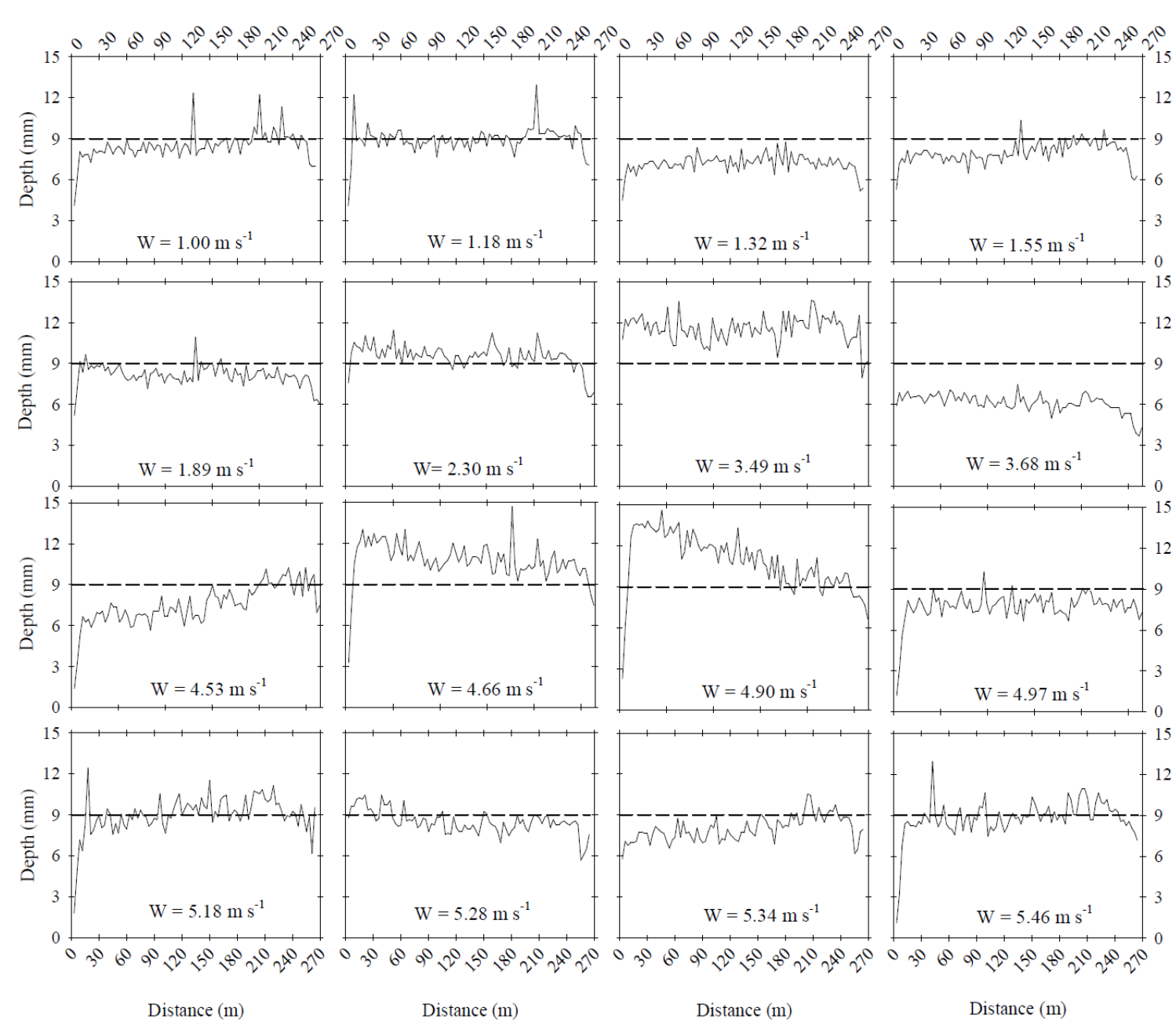

Figure 1 - Water distribution patterns of the lateral move equipment operating in the different wind speeds $(\mathrm{W})$ in which the tests were conducted. 
the 16 in-field tests, in different wind speed conditions. Irrigation depths were found to have greater amplitude up to $75 \mathrm{~m}$ from the beginning of the equipment (Figure 1). This behavior is in accordance with what was observed by CHAVES et al. (2010), to a mechanical lateral move irrigation system. According to these authors, variations in the amplitude of the irrigation depths collected in the first two towers of the equipment is resultant from the displacement system mechanism of the linear move equipment.

It can also be observed in figure 1 a variation among the values of the irrigation depth collected during the tests. This occurs to similar values of wind speed, according to CHAVES et al. (2010), possibly due to the skid of the equipment, and, according to FOLEGATTI et al. (1998), due to the random movement of the towers in relation to the alignment of the last tower.

The results presented in figure 1 also indicate that for the in-field tests conducted under wind speed equal to 3.49 and $4.66 \mathrm{~m} \mathrm{~s}^{-1}$, the average collected irrigation depth was greater than that regulated in the equipment percentimeter $(9 \mathrm{~mm})$. This allows to infer that the equipment was moving with velocity other than that regulated in its control panel. Additionally, this fact can be attributed to a possible skid of the equipment (CHAVES et al., 2010).

Therefore, aside from weather factors, operational factors of the equipment also contribute to its irregular performance, corroborating with KINCAID (1996), who affirms that the variation of the equipment movement velocity and the high wind speed are the factors that most affect the water distribution uniformity of central pivot and/or linear move irrigation systems.

The measured values for wind speed and direction during the 16 in-field tests, as well as the time when they were done and the values of CU and DU obtained are presented in table 1.

One can infer from in table 1 that wind direction was observed in different directions in relation to the lateral line of the equipment during the in-field tests. There were no different values of wind direction for similar wind speed and this can be attributed to the fact that this study was done in in-field with real operational conditions, having some inherent difficulties. Also, it could be noted that wind direction tended to cause little influence on CU and DU values. However, it was found that the greater was the wind speed, the lesser were the uniformity coefficients (CU and DU), corroborating with TARJUELO et al. (1992) and DUKES (2006).

The values of Christiansen uniformity coefficient (CU) obtained in the 16 in-field tests varied from $85.00 \%$ to $93.86 \%$ (Table 1), that is, the values of CU were classified as "very good" and "good" according to the NBR 14244 norm (ABNT, 1998), and they were found to be close to the ones observed by CAINELLI et al. (1997).

On the other hand, the values of the distribution uniformity coefficient (DU), more restrictive than the values of $\mathrm{CU}$, ranged from $76.41 \%$

Table 1 - Uniformity coefficients observed in 16 in-field tests of the linear move irrigation equipment.

\begin{tabular}{|c|c|c|c|c|c|}
\hline Date & Start time of the in-field test & Wind direction $\left({ }^{\circ}\right)$ & Wind speed $\left(\mathrm{m} \mathrm{s}^{-1}\right)$ & $\mathrm{CU}(\%)$ & DU (\%) \\
\hline $03 / 12 / 2014$ & 11:44 AM & 103.3 & 1.89 & 93.64 & 89.26 \\
\hline $03 / 13 / 2014$ & 09:25 AM & 325.8 & 3.68 & 88.56 & 78.57 \\
\hline $03 / 13 / 2014$ & $11: 32 \mathrm{AM}$ & 329.6 & 2.30 & 89.50 & 82.59 \\
\hline $03 / 14 / 2014$ & $10: 38 \mathrm{AM}$ & 185.4 & 5.28 & 92.69 & 88.26 \\
\hline $03 / 14 / 2014$ & 02:48 PM & 161.5 & 5.34 & 90.81 & 86.04 \\
\hline $03 / 21 / 2014$ & 10:53 AM & 317.9 & 4.66 & 91.75 & 85.90 \\
\hline $03 / 21 / 2014$ & $11: 46 \mathrm{AM}$ & 317.1 & 5.18 & 89.97 & 82.82 \\
\hline $03 / 22 / 2014$ & $10: 23 \mathrm{AM}$ & 205.6 & 4.97 & 91.66 & 85.10 \\
\hline $03 / 22 / 2014$ & 12:19 PM & 357.8 & 5.46 & 90.83 & 84.54 \\
\hline $03 / 22 / 2014$ & 01:34 PM & 11.25 & 4.90 & 85.00 & 76.41 \\
\hline $03 / 22 / 2014$ & 02:32 PM & 8.44 & 4.53 & 85.36 & 78.82 \\
\hline $03 / 23 / 2014$ & 08:54 AM & 155.6 & 1.32 & 93.89 & 89.01 \\
\hline $03 / 23 / 2014$ & 09:56 AM & 182.8 & 1.00 & 93.18 & 88.51 \\
\hline $03 / 23 / 2014$ & 10:59 AM & 93.0 & 1.18 & 93.86 & 88.80 \\
\hline $03 / 23 / 2014$ & 12:37 PM & 186.1 & 1.55 & 92.80 & 88.27 \\
\hline $03 / 23 / 2014$ & 02:58 PM & 135.8 & 3.49 & 93.15 & 89.02 \\
\hline
\end{tabular}


to $89.26 \%$, with a mean rate of $85.12 \%$ (Table 1 ). These values are similar to the ones found by CAINELLI et al. (1997), thus, all the tests were classified as "very good" and "good" according to the classification proposed by MERRIAN \& KELLER (1978).

It should be mentioned that even with wind speed greater than the ones recommended by NBR 14244 (ABNT, 1998) for the tests in order to evaluate sprinkler irrigation systems, values of CU and DU were classified as good or superior. It is important to emphasize the technological advances of the last decades, with the creation of rotating plate sprinklers, like the ones used in this study. Such improvement has as goal to increase the water distribution patterns of the sprinklers, when compared to the fixed plate sprinklers, and, consequently, to make them less susceptible to the harmful effects of the wind.

FACI et al. (2001) reported that water distribution pattern on an irrigated area under high wind speeds is just a little distorted in rotating plate sprinklers and only has its distribution pattern moved towards the predominant wind direction. According to these authors, this minimizes the negative influence of this factor on the water distribution uniformity. This justifies the high uniformity values found in this study.

The resulting values of CU and DU for each in-field test are related to each other and depicted in figure 2A. There was a clear linear relation between $\mathrm{CU}$ and DU (Figure 2A) and this behavior was also described by DUKES (2006) to a mechanical lateral move irrigation equipment, and by KELLER \& BLIESNER (1990), TARJUELO et al. (1999) and TOROMO et al. (2011) in studies with conventional sprinkler systems.

Comparing the adjustments between $\mathrm{CU}$ and DU obtained by KELLER \& BLIESNER (1990), TARJUELO et al. (1999) and TOROMO et al. (2011) with that obtained in this study (Figure $2 \mathrm{~B})$, the behavior can be considered similar. One aspect that deserves attention is the fact that in all the in-field tests the values of Christiansen's Uniformity were greater than the values of Distribution Uniformity, behavior also observed by the above mentioned authors.

\section{CONCLUSION}

The greater was the wind speed, the lower were the values of the uniformity coefficient observed in this study.

Even in unfavorable wind conditions, the mechanical lateral move equipment used in rice irrigation in the South of Rio Grande do Sul State, Brazil, presented desirable indexes of water distribution uniformity.

Because only a few studies related to water distribution evaluation specifically for mechanical lateral move irrigation systems have been observed, the authors recommend to conduct more researches in

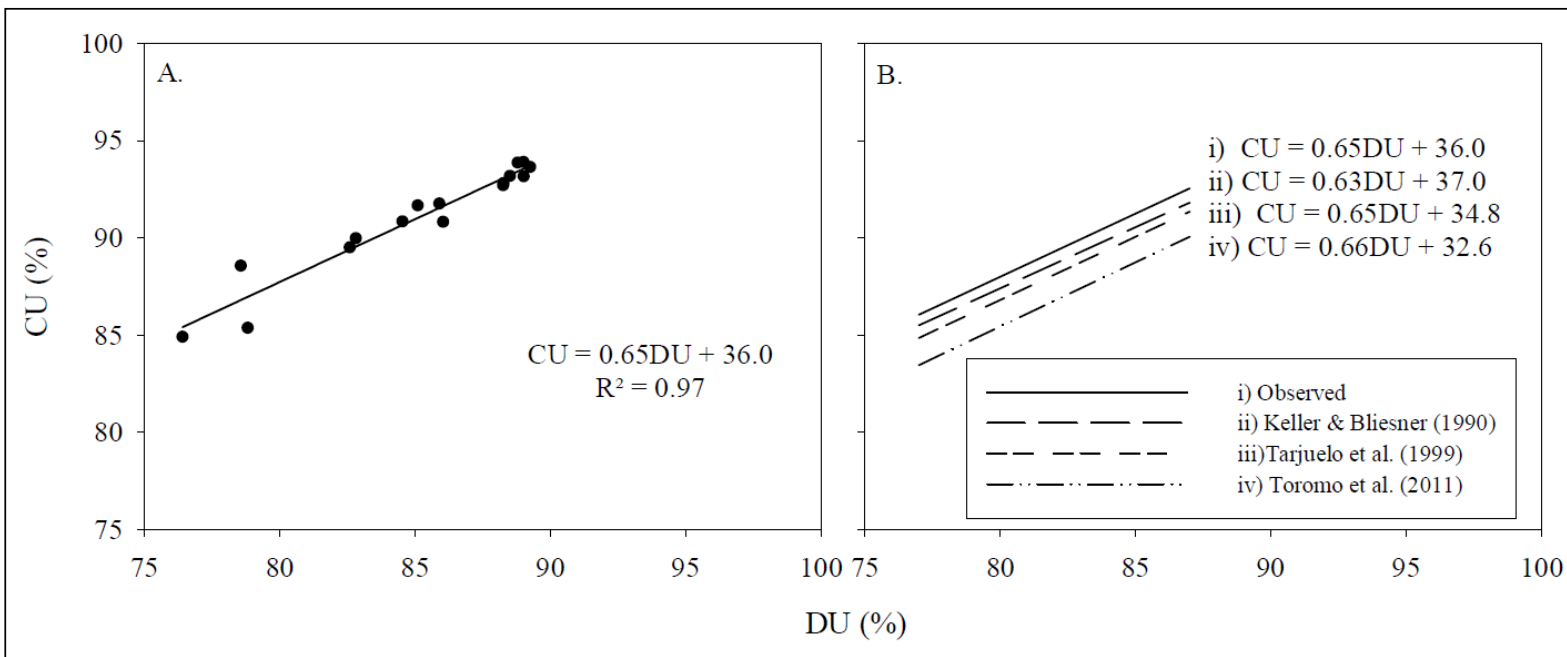

Figure 2 - A) Relation between the values of CU and DU considering the in-field test; and B) comparison of the relationship obtained in this study with those observed in other studies. 
which other weather and operational conditions can be considered.

\section{ACKNOWLEDGMENTS}

To Conselho Nacional de Desenvolvimento Científico e Tecnológico (CNPq) for the financial support in the acquisition of the equipments and the materials used in this study (process: 479792/2013-5).

To Empresa Brasileira de Pesquisa e Agropecuária (EMBRAPA), Campo Experimental de Terras Baixas (ETB), Pelotas, RS.

\section{REFERENCES}

ABNT (ASSOCIAÇÃO BRASILEIRA DE NORMAS TÉCNICAS). NBR 14244: equipamentos de irrigação mecanizada Pivô central e lateral móvel providos de emissores fixos ou rotativos Determinação da uniformidade de distribuição de água. Rio de Janeiro, 1998. 11p.

ASAE (AMERICAN SOCIETY OF AGRICULTURAL ENGINNEERING). Standard 436.1. Test procedure for determining the uniformity of water distribution of center pivot and lateral move irrigation machines equipped with spray or sprinkler nozzles. St. Joseph, Michigan, 1996. $8 \mathrm{p}$.

BESKOW, S. et al. Modeling of evaporation and wind drift losses in medium-pressure sprinklers. Revista Brasileira de Engenharia Agrícola e Ambiental, v.15, n.3, p.221-228, 2011. Available from: <http://dx.doi.org/10.1590/S141543662011000300001>. Accessed: Aug. 08, 2014. doi: 10.1590/ S1415-43662011000300001.

CAINELLI, V.H. et al. Desempenho e uniformidade da distribuição de água de um pivô central. Ciência Rural, v.27, n.4, p.35-40, 1997. Available from: <http://www.scielo.br/scielo.php?pid=S010384781998000100006\&script $=$ sci_arttext $>$. Accessed: Aug. 25, 2014. doi: 10.1590/S0103-84781998000100006.

CHAVES, J.L. et al. Compensating inherent linear move water application errors using a variable rate irrigation system. Irrigation Science, v.28, p.203-210, 2010. Available from: $<$ http://dx.doi. org/10.1007/s00271-009-0188-6>. Accessed: Aug. 08, 2014. doi: 10.1007/s00271-009-0188-6.

CHRISTIANSEN, J.E. Irrigation by sprinkling. Berkeley: University of California, 1942. 124p. (Bulletin, 670).

CRUSCIOL, C.A.C. et al. Fornecimento de água por meio de irrigação por aspersão para produção de sementes de arroz de terras altas. Bioscience Journal, v.28, n.1, p.34-42, 2012. Available from: <http://www.seer.ufu.br/index.php/biosciencejournal/article/ view/12163>. Accessed: Aug. 08, 2014.

DECHMI, F. et al. Wind effects on solid set sprinkler irrigation depth and yield of maize (Zea mays). Irrigation Science, v.22, p.67-77, 2003. Available from: $<$ http://link.springer.com/article/1 0.1007\%2Fs00271-003-0071-9>. Accessed: Mar. 18, 2015. doi: 10.1007/s00271-003-0071-9.
DUKES, M.D. Effect of wind speed and pressure on linear move irrigation system uniformity. Applied Engineering in Agriculture, v.22, n.4, p.541-548, 2006. Available from: <http:// dx.doi.org/10.13031/2013.21222>. Accessed: Aug. 08, 2014. doi: $10.13031 / 2013.21222$

FACI, J.M. et al. Comparison of fixed and rotating spray plate sprinklers. Journal of Irrigation and Drainage Engineering, v.127, p.224-233, 2001. Available from: <http://dx.doi. org/10.1061/(ASCE)0733-9437(2001)127:4(224)>. Accessed: Aug. 08, 2014. doi: 10.1061/(ASCE)0733-9437(2001)127:4(224).

FOLEGATTI, M.V. et al. Avaliação do desempenho de um pivô central de grande porte e baixa pressão. Scientia Agricola, v.55, n.1, p.119-127, 1998. Available from: <http://dx.doi.org/10.1590/ S0103-90161998000100019>. Accessed: Aug. 08, 2014. doi: 10.1590/S0103-90161998000100019.

GONÇALVES, M.A. et al. Qualidade de fruto e produtividade de pessegueiros submetidos a diferentes épocas de poda. Ciência Rural, v.44, n.8, p.1334-1340, 2014. Available from: <http:// dx.doi.org/10.1590/0103-8478cr20120617>. Accessed: Sept. 15, 2014. doi: $10.1590 / 0103-8478$ cr20120617.

HEINEMANN, A.B. et al. Influência da altura do emissor na uniformidade de distribuição da água de um sistema pivô central. Pesquisa Agropecuária Brasileira, v.33, n.9, p.1487-1491, 1998.

KELLER, J.; BLIESNER, R.D. Sprinkle and trickle irrigation. New York: AnaviBook/Van Nostrand Reinhold, 1990. 652p.

KINCAID, D.C. Application uniformity of low pressure center pivot equipment. In: WINTER COMMODITY SCHOOLS, 1996, USA-ID-Burley. Proceedings... WCS: University of Idaho, 1996. p.91-93. Available from: $<$ http://eprints.nwisrl.ars.usda.gov/ id/eprint/1087>. Accessed May 09, 2014.

MERRIAN, J.L; KELLER, J. Irrigation system evaluation. A guide for management. Logan: Utah State University, 1978. 271p.

SANCHEZ, I. et al. The spatial variability of the Wind in a sprinkler irrigated district: Implications for irrigation management. Biosystems Engineering, v.109, p.65-76, 2011. Available from: $<$ http://dx.doi. org/10.1016/j.biosystemseng.2011.02.003>. Accessed: Mar. 18, 2015. doi: 10.1016/j.biosystemseng.2011.02.003.

TARJUELO, J.M. et al. Irrigation uniformity with medium size sprinklers part II: Influence of wind and other factors on water distribution. Transactions of the ASAE, v.42, n.3, p.677-689, 1999. Available from: <http://dx.doi.org/10.13031/2013.13229>. Accessed; Aug. 08, 2014. doi: 10.13031/2013.13229.

TARJUELO, J.M. et al. Working conditions of sprinkler to optimize application water. Journal of Irrigation and Drainage Engineering, v.118, p.895-913, 1992. Available from: $<\mathrm{http}: / / \mathrm{dx}$.doi. org/10.1061/(ASCE)0733-9437(1992)118:6(895)>. Accessed; Aug. 08, 2014. doi: 10.1061/(ASCE)0733-9437(1992)118:6(895).

TOROMO, A.K. et al. Can shelterbelts improve sprinkler irrigation performance under windy semi-arid conditions? Irrigation and Drainage Systems, v.25, p.335-345, 2011. Available from: $<$ http://dx.doi.org/ 10.1007/s10795-012-9128-3>. Accessed: Aug. 08, 2014. doi: 10.1007/s10795-012-9128-3. 